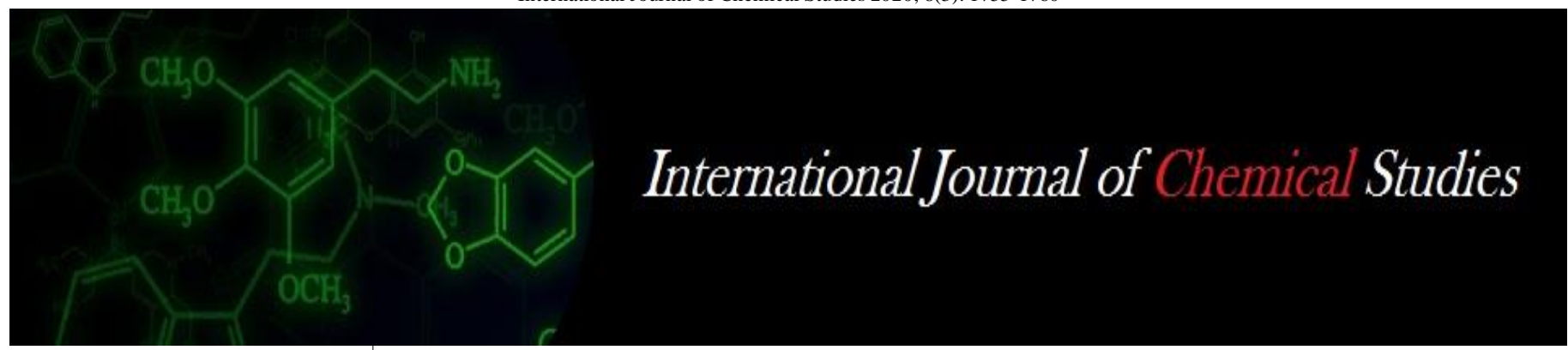

P-ISSN: 2349-8528

E-ISSN: 2321-4902

www.chemijournal.com

IJCS 2020; 8(3): 1755-1760

(C) 2020 IJCS

Received: 14-03-2020

Accepted: 16-04-2020

Chandraprakash Verma

M.Sc. Scholar, Department of

Agronomy, Indra Gandhi Krishi

Vishwavidyalaya, Raipur

Chhattisgarh, India

Dr. Vivek Kumar Tripathi Principal Scientist (Agronomy) and Associate Director Research, IGKV, Raipur, Chhattisgarh, India

Lok Prakash Verma M.V.Sc. Scholar, Department of Veterinary and Animal Husbandry Extension, GBPUAT, Pantnagar,

Uttarakhand, India

Dr. Indrapal Singh Paikra Ph.D. Scholar, Department of Agronomy, Indra Gandhi Krishi Vishwavidyalaya, Raipur, Chhattisgarh, India
Corresponding Author: Chandraprakash Verma M.Sc. Scholar, Department of Agronomy, Indra Gandhi Krishi Vishwavidyalaya, Raipur, Chhattisgarh, India

\section{Effect of ridge and furrow system in soybean cultivation and feasibility of economics}

\author{
Chandraprakash Verma, Dr. Vivek Kumar Tripathi, Lok Prakash Verma \\ and Dr. Indrapal Singh Paikra
}

DOI: $\underline{\text { https://doi.org/10.22271/chemi.2020.v8.i3x.9451 }}$

\begin{abstract}
Optimum plant population is pre requisite obtain higher seed production and productivity of soybean. In this study soybean variety RSC 1046 was recorded significant higher plant population, Plant height, number of branches plant ${ }^{-1}$ dry matter accumulation plant ${ }^{-1}$, Leaf area index plant ${ }^{-1}$ and seed yield. Crop geometry was recorded significant maximum plant population and plant height in $45 \times 5$, number of branches plant ${ }^{-1}$ and dry matter accumulation plant ${ }^{-1}$ in $45 \times 10$ leaf area index plant ${ }^{-1}$ in $45 \times 5$ and seed yield in $45 \times 10$. Interaction effect in seed yield was recorded between variety and crop geometry $(\mathrm{cm})$. RSC 1046 and $45 \times 10$ show significant higher seed yield. Relationship between plant population and seed yield $\left(\mathrm{kg} \mathrm{ha}^{-1}\right)$ was linear with performance maximum in variety RSC 1046 and crop geometry $(\mathrm{cm})$ $45 \times 10$. That results shows optimum plant population due to variety and crop geometry produce higher pre harvest parameters and yield soybean planted in ridge and furrow system. Economic as a basic effect on farmer economy due to cost of cultivation, gross return, net return and net return per rupee investment. This research was recorded varieties cost of cultivation is same but crop geometry this are changed. Higher cost of cultivation in crop geometry $45 \times 5$ and lowest in $45 \times 30$. There was gross return, net return and net return per rupee investment higher in variety RSC 1046 and lowest in CG Soya 1. Crop geometry was recorded highest gross return, net return and net return per rupee investment in $45 \times 10$ and lowest in $45 \times 30$. Economics feasibilities are important to farmer economic condition due to adopt farming system.
\end{abstract}

Keywords: Variety, CG Soya 1, RSC 1046, crop geometry, ridge and furrow system

\section{Introduction}

Soybean (Glycine max. L.) ranks first amongst oilseed crops in the world and it contributes nearly 25 per cent of world's total oil and fat production. Soybean (Glycine max L. Merrill) is known as the Golden Bean of the $21^{\text {st }}$ century. It is a legume but widely grown for oil purpose. It is one of the important oilseed crop and ranked second among oilseed crops of India. It is the only crop which has been included both in the categories of oilseed and pulses. It is the cheapest, richest and easiest source of best quality protein. Owing to multiplicity of uses as food and industrial products, soybean is called as wonder crop. Chemical analysis revealed that soybean seed contains approximately $20 \%$ oil, $40 \%$ protein, $30 \%$ carbohydrates, $10 \%$ total sugar and $5 \%$ ash. Further, soybean meal also has high content of minerals, particularly calcium, phosphorus and iron ${ }^{[1,2]}$ and its seed oil is rich in essential fatty acids ${ }^{[3]}$. Its protein is complete and contains all the essential amino acids therefore all nutrition factors terms truly it's as miracle bean. Soybean is an environment friendly grain legume and its builds up the soil fertility by fixing a large amount of atmospheric nitrogen through the root nodules and leaf fall on the ground at maturity. The nodulated soybean plants can be fix about $94 \mathrm{~kg}$ of nitrogen ha${ }^{1}$ in one crop season ${ }^{[4]}$ (Sattar, 2001). India is the lead third postion of largest edible oil economy in the world after USA and China. In India, during 2000, its cultivation occupies an area of 12.2 million hectares with production was 89.19 lakh tones 2015-16 along with average productivity of $922 \mathrm{~kg} \mathrm{ha}^{-1} 2017-18^{[5]}$. The crop experiences moisture stress during the dry spell ranging from 15 to 21 days at any growth stage under rainfed conditions, resulting significant reduction in the yield ${ }^{[6]}$. These yield losses are expected at higher level especially in early genotype with determinate types. At present for extensively cultivation of Kharif crop like soybean which faces the problem of water logging and poor aeration thereby affecting crop productivity adversely. Among all legumes soybean is most sensitive to soil 
moisture. After few showers the monsoon rains in July August are usually heavy and frequent. Under such situation water logging is a common problem which affects early growth, root proliferation and final yield performance of crop. Excess and continuous rains may create bad drainage and restricts aeration, which results in non-availability of plant nutrients and poor microbial activities. Extreme variability in the quantity, time and duration of rains expose the soybean crop to soil moisture deficit as well as excess moisture either on account of delayed monsoon, longer dry spells or early withdrawal monsoon has been identified as one of the major factors for poor performance of soybean crops. ${ }^{[7,8]}$. During too extreme rainfalls events, soybean crop gets also affected by water logging problems due to improper drainage. Water logging adversely affects the growth of crops, primarily due to reduced oxygen supply to the roots ${ }^{[6]}$. Studies on soil management for increasing crop production revealed that use of various tillage methods and modification of land configurations such as broad bed furrow, ridges and furrow for soybean in vertisols were superior over flat bed and recommended in watershed development for moisture conservation as well as for safe removal of excess rain water [9]. The small change through land configuration in normal line or flat field conditions may help in improving the productivity of Kharif crops in Vertisols in gird region. There is a need for in-situ soil and water conservation and proper drainage technology in black soils. This technology has many advantages including in-situ conservation of rainwater in furrows, better drainage of excess water and proper aeration in the ridge and root zone. The strategy for soil moisture management is therefore; to maximize use of rainfall by increasing infiltration and moisture retention, encourage surface drainage and reducing runoff and soil erosion for getting high yield. The yield in recommended practice (ridge and furrow system) increased $30.18 \%$ over farmer practice i.e. normal line sowing system ${ }^{[10]}$. In view of the above fact the study was underta ken. This paper presents the results of ridge and furrow system on growth parameters, yield attributing characters, yield and economics fesibilities of soybean cultivation

\section{Material and methods}

A field experiment was conducted at Research cum Instructional Farm, IGKV, Raipur, during rainy season of 2018. The experimental soil was clay in texture with $\mathrm{pH} 7.42$ EC $0.30 \mathrm{dsm}^{-1}$, organic carbon $0.64 \%$, low in available nitrogen $\left(231.7 \mathrm{~kg} \mathrm{ha}^{-1}\right)$, medium in phosphorus $\left(22.71 \mathrm{~kg} \mathrm{ha}^{-}\right.$ $\left.{ }^{1}\right)$ and high in available potassium $\left(346.4 \mathrm{~kg} \mathrm{ha}^{-1}\right)$. The experiment was laid out in split plot design with three replication. The treatments was consisted of two varieties CG Soya 1 and RSC 1046 and four crop geometry(cm) 45× 5, $45 \times 10,45 \times 5$ and $45 \times 10$. Varieties in main plant and crop geometry in sub plot are adopted. Crop was sown in first week of july. Recommand dose of fertilizer applied $25 \mathrm{~kg} \mathrm{ha}^{-1}$ of nitrogen, $40 \mathrm{~kg} \mathrm{ha}^{-1}$ phosphorus and $60 \mathrm{~kg} \mathrm{ha}^{-1}$ potassium. Crop planting was third July and harvest in last week of October. Five plants were taken for recording growth parameters. The seed yield was taken plot wise and converted into $\mathrm{kg} \mathrm{ha}^{-1}$. Optimum plant population and crop geometry are important factor for obtaining high seed yields of soybean. They was depend upon crop economics condition of farmer. The aim of the present study was to find out optimum economics pattern for farmer economy in planted on ridge and furrow system.

\section{Economic analysis}

Harvest index

The harvest index was determined by using the formula given by Donald ${ }^{[11]}$.

$$
\text { Harvest index }(\%)=\frac{\text { Economic yield }}{\text { Biological yield }} \times 100
$$

Where,

Economic yield $=$ Seed yield

Biological yield $=$ Seed yield + Stover yield

\section{Cost of cultivation}

The cost of cultivation $\left(\mathrm{Rs} \mathrm{ha}^{-1}\right)$ of each treatment was worked out by considering the price of inputs, charges for cultivation, labour and other charges.

\section{Gross returns}

The gross returns $\left(\mathrm{Rs} \mathrm{ha}^{-1}\right)$ occurred due to different treatments in the present study were worked out by considering market prices of economic product, by product and crop residues during the experimental year.

\section{Net returns}

The net returns $\left(\mathrm{Rs} \mathrm{ha}^{-1}\right)$ of each treatment were worked out by deducting the mean cost of cultivation of each treatment from the gross monetary returns gained from the respective treatments.

\section{Net return per rupee investment}

The net return per rupee investment of each treatment was calculated by dividing the net returns by the mean cost of cultivation.

\section{Result discussion \\ Effect of varieties and crop geometry in growth parameters of soybean}

The data was showed in Table 1 and Figures 1 and 2. The result revealed that variety RSC 1046 was recorded significant maximum tallest plant, maximum number of branches plant ${ }^{-1}$, and dry matter accumulation plant ${ }^{-1}$ and leaf area index as compared to CG Soya 1 . Crop geometry $(\mathrm{cm})$ was recorded significant tallest plant in $45 \times 5$, followed by $45 \times 10,45 \times 20$ and smallest in $45 \times 30$. The increase in plant height at closer spacing might have been caused due to increased plant population density. The higher population density caused mutual shading in plants that contributed to stem elongation and ultimately plant height increased. Similar results were also reported by $[12,13]$. Crop geometry was recorded significantly maximum number of branches plant ${ }^{-1}$ in $45 \times 30$, followed by $45 \times 20,45 \times 10$ and lowest in $45 \times 5$. Narrow spacing planting of crop increasing plant densities, increase of plant density, decreased the number of branches plant $^{-1}$ due to plants at higher densities accumulate less carbon which is not sufficient to support more branching. Similar results have been reported by ${ }^{[14,15,16,17]}$. Crop geometry was recorded significantly maximum dry matter accumulation in $45 \times 30$, followed by $45 \times 20,45 \times 10$ and lowest in $45 \times 5$. Dry matter accumulation were highest in ridge sowing as compared to flat sowing. Growth and yield attributes were highest in ridge sowing ${ }^{[18]}$. Crop geometry was recorded significant maximum leaf area index plant ${ }^{-1}$ in $45 \times 5$, followed by $45 \times 10,45 \times 20$ and minimum in $45 \times 30$. Also be reported that leaf area index increased with increasing plant density its direct related to close plant spacing ${ }^{[19]}$. 


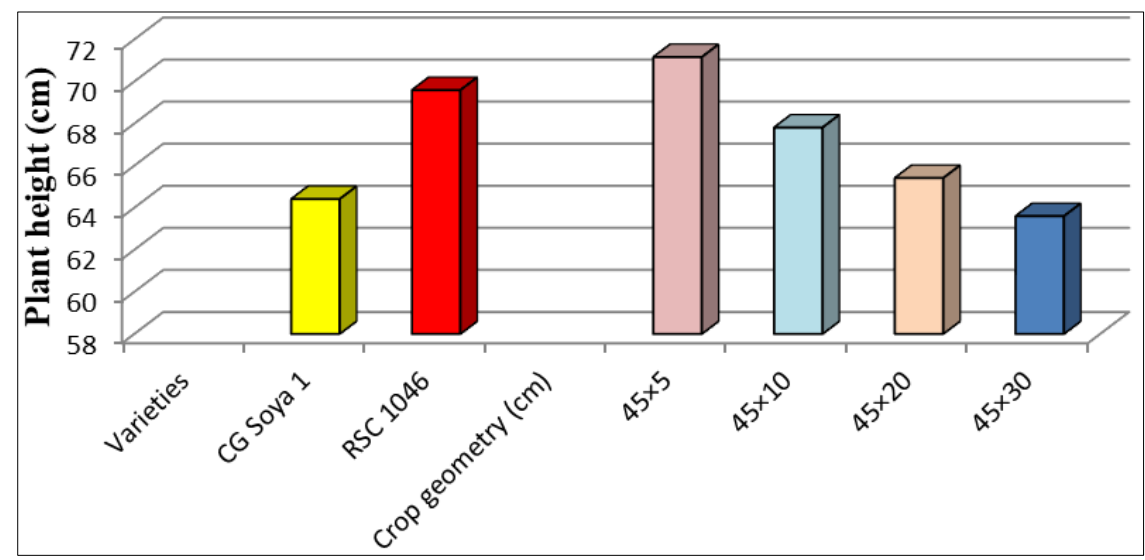

Fig 1: Plant height $(\mathrm{cm})$ as influenced by varieties and newly released soybean varieties planted in ridge and furrow system

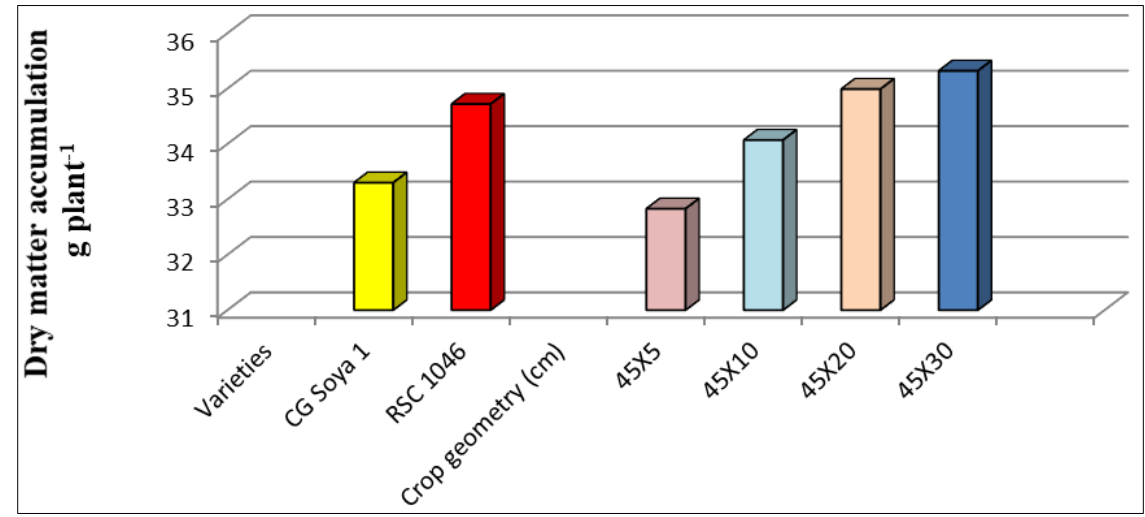

Fig 2: Dry matter accumulation g plant $^{-1}$ influenced by varieties and newly released soybean varieties planted in ridge and furrow system

Table 1: Response of newly released soybean varieties and crop geometry planting in ridge and furrow system on growth parameters of soybean

\begin{tabular}{|c|c|c|c|c|}
\hline Treatment & Plant height (cm) & No. of branches plant ${ }^{-1}$ & Dry matter accumulation g plant ${ }^{-1}$ & leaf area index \\
\hline \multicolumn{5}{|c|}{ Varieties } \\
\hline CG Soya 1 & 64.41 & 6.21 & 33.3 & 2.45 \\
\hline RSC 1046 & 69.59 & 6.88 & 34.72 & 2.68 \\
\hline S.Em \pm & 0.62 & 0.02 & 0.21 & 0.02 \\
\hline $\mathrm{CD}(\mathrm{P}=0.05 \%)$ & 1.62 & 0.08 & 0.84 & 0.03 \\
\hline \multicolumn{5}{|c|}{ Crop geometry $(\mathrm{cm})$} \\
\hline $45 \times 5$ & 71.16 & 5.91 & 32.83 & 4.82 \\
\hline $45 \times 10$ & 67.81 & 6.33 & 34.07 & 2.91 \\
\hline $45 \times 20$ & 65.41 & 6.66 & 34.99 & 1.46 \\
\hline $45 \times 30$ & 63.6 & 7.25 & 35.32 & 1.05 \\
\hline $\mathrm{S} . \mathrm{Em} \pm$ & 0.77 & 0.17 & 0.22 & 0.02 \\
\hline $\mathrm{CD}(\mathrm{P}=0.05 \%)$ & 1.83 & 0.54 & 0.7 & 0.1 \\
\hline
\end{tabular}

Effect of varieties and crop geometry in yield attributes and yield of soybean

The data was showed in Table 2 and 3 and figures in 3, 4, 5, 6 and 7. Significantly maximum plant population (No $\left.\mathrm{m}^{2}\right)$ was recorded in variety RSC 1046 and lowest in CG Soya 1. Crop geometry $(\mathrm{cm})$ was recorded significantly maximum plant population in $45 \times 5$, followed by $45 \times 5,45 \times 5$ and lowest in $45 \times 30$. The data revealed that significantly higher number of pods plant ${ }^{-1}$ was recorded in variety RSC 1046 and lowest in CG Soya 1 . Crop geometry $(\mathrm{cm})$ was recorded significant higher number of pods plant ${ }^{-1}$ in $45 \times 10$ and lowest in $45 \times 5$. The data revealed that significantly maximum number of seed pod $^{-1}$ was recorded in variety RSC 1046 and lowest in CG Soya 1 . Crop geometry $(\mathrm{cm})$ was recorded significant higher number of seeds pod $^{-1}$ in $45 \times 10$ was and lowest in $45 \times 5.100$ seed weight $(\mathrm{g})$ was recorded no significant difference in varieties and crop geometry. Narrow row and plant spacing ensured early canopy coverage and maximum light interception, crop growth rate and crop biomass, resulting in increased number of pod plant ${ }^{-1}$, no. of seed pod $^{-1}$ and yield potential per unit area. Similar results have been reported by $[20,21]$. Soybean was recorded significant higher seed yield in variety RSC 1046 and lowest seed in CG Soya 1. Crop geometry was recorded significant seed yield in $45 \times 10$ and minimum seed yield in $45 \times 30$. The interaction effect observed in seed yield. interaction show combination of treatment variety and Crop geometry $(\mathrm{cm})$ was highest seed yield obtained in RSC 1046 with spacing $45 \times 10$ and lowest in CG Soya 1 with Spacing $45 \times 30$. He was reported that higher seed yield at the highest plant population level due to better plant growth, more pod per unit area and higher biological yield. Relationship between plant population and seed yield ( $\mathrm{kg} \mathrm{ha}^{-}$ $\left.{ }^{1}\right)$ was linear with performance maximum in variety RSC 1046 and crop geometry (cm) $45 \times 10^{[22]}$. 


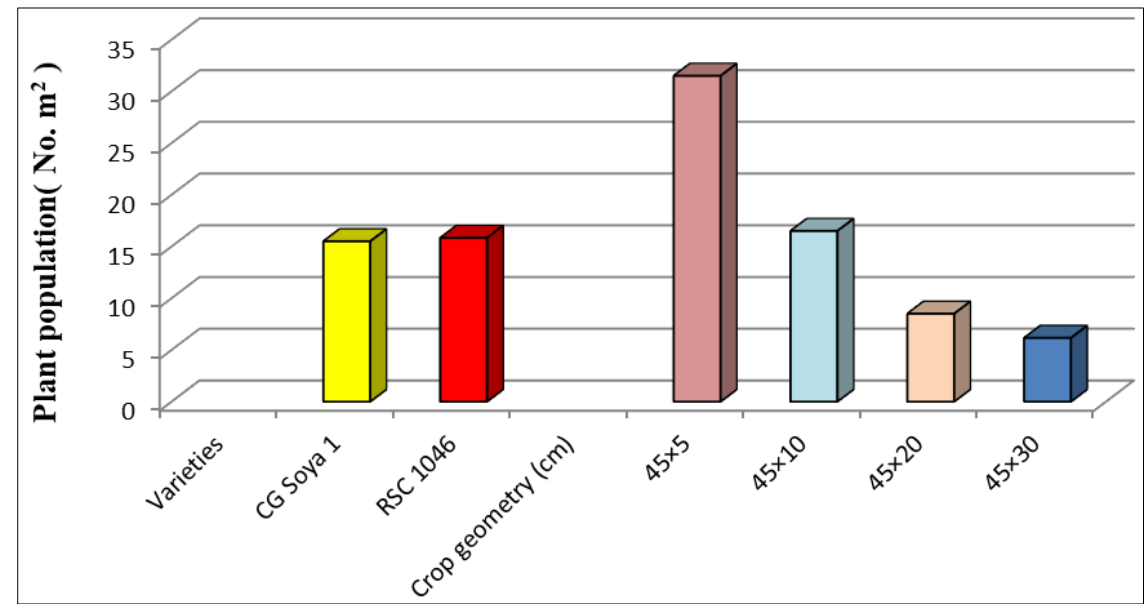

Fig 3: Plant population (No. $\mathrm{m}^{2}$ ) as influenced by varieties and newly released soybean varieties planted in ridge and furrow system

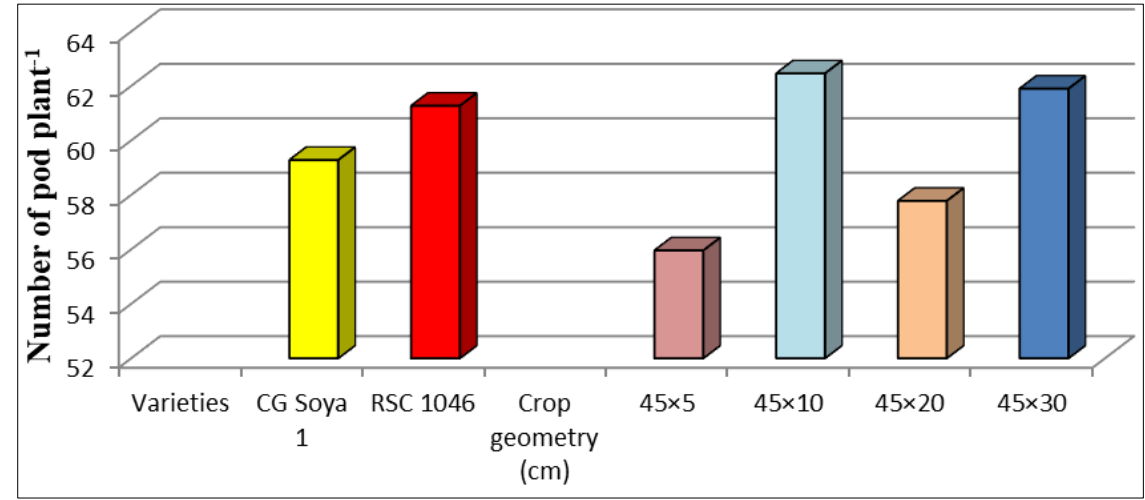

Fig 4: Number of pod plant ${ }^{-1}$ as influenced by varieties and newly released soybean varieties planted in ridge and furrow system

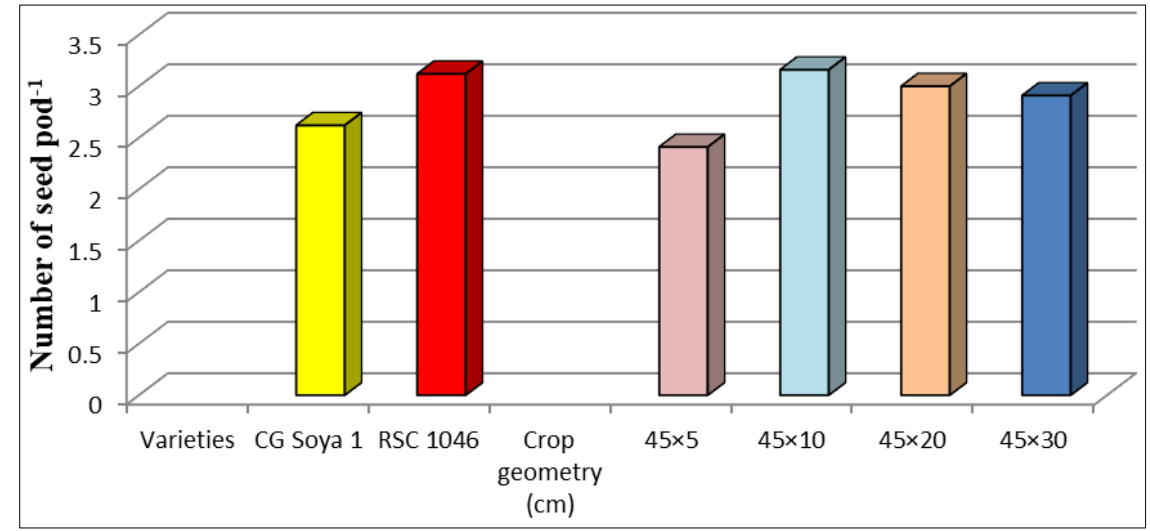

Fig 5: Number of seed pod $^{-1}$ as influenced by varieties and newly released soybean varieties planted in ridge and furrow system

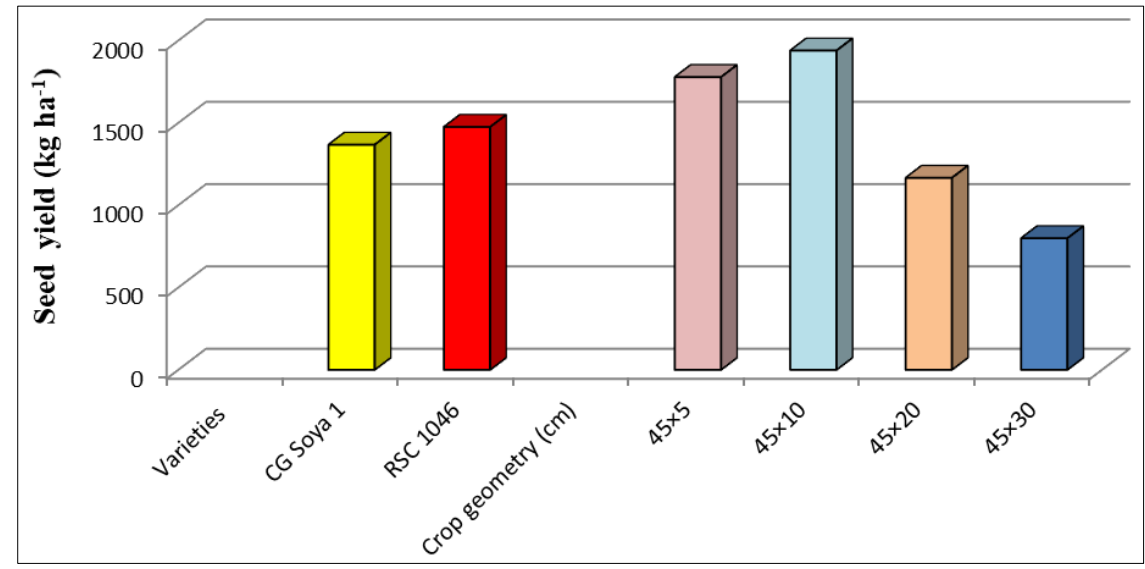

Fig 6: Seed yield $\left(\mathrm{kg} \mathrm{ha}^{-1}\right)$ as influenced by varieties and newly released soybean varieties planted in ridge and furrow system 


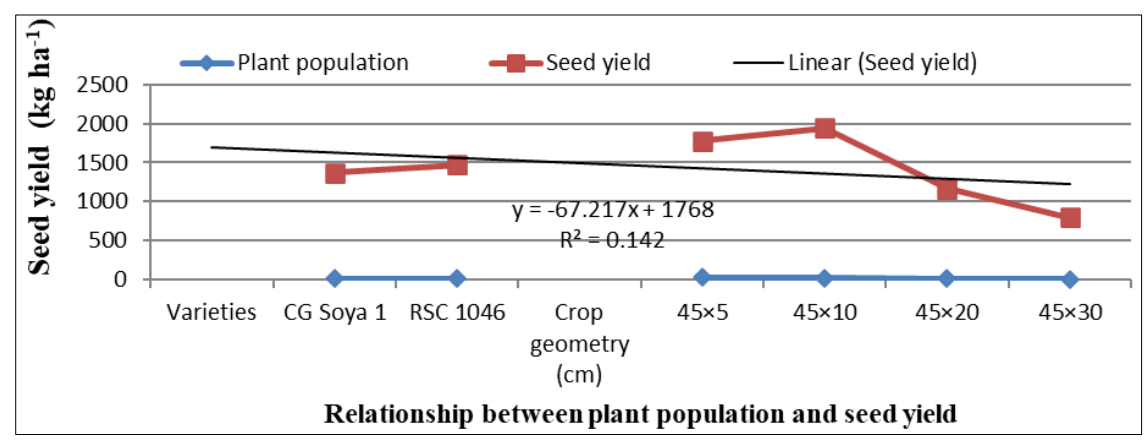

Fig 7: Relationship (regression) between plant population (No. $\mathrm{m}^{2}$ ) and seed yield $\left(\mathrm{kg} \mathrm{ha}^{-1}\right)$ as influenced by varieties and newly released soybean varieties planted in ridge and furrow system

Table 2: Response of newly released soybean varieties and crop geometry planting in ridge and furrow system on yield attributing parameters and yield

\begin{tabular}{|c|c|c|c|c|c|}
\hline Treatment & Plant population (No. $\mathrm{m}^{2}$ ) & No. of pods plant ${ }^{-1}$ & No of seed pod ${ }^{-1}$ & 100 seed weight & Seed Yield $\left(\mathrm{kg} \mathrm{ha}^{-1}\right)$ \\
\hline \multicolumn{6}{|c|}{ Varieties } \\
\hline CG Soya 1 & 15.50 & 59.28 & 2.62 & 10.02 & 1367 \\
\hline RSC 1046 & 15.83 & 61.27 & 3.12 & 10.13 & 1475 \\
\hline S.Em \pm & 0.03 & 0.28 & 0.03 & 0.06 & 14.9 \\
\hline $\mathrm{CD}(\mathrm{P}=0.05 \%)$ & 0.16 & 1.09 & 0.14 & NS & 58.53 \\
\hline \multicolumn{6}{|c|}{ Crop geometry $(\mathrm{cm})$} \\
\hline $45 \times 5$ & 31.5 & 55.96 & 2.41 & 10.16 & 1778 \\
\hline $45 \times 10$ & 16.5 & 62.46 & 3.16 & 10.21 & 1939 \\
\hline $45 \times 20$ & 8.50 & 57.78 & 3 & 10.34 & 1166 \\
\hline $45 \times 30$ & 6.16 & 61.9 & 2.91 & 10.46 & 799 \\
\hline S.Em \pm & 0.23 & 0.89 & 0.11 & 0.19 & 51.7 \\
\hline $\mathrm{CD}(\mathrm{P}=0.05 \%)$ & 0.72 & 2.75 & 0.34 & NS & 159.33 \\
\hline
\end{tabular}

Table 3: Interaction effect of seed yield $\left(\mathrm{kg} \mathrm{ha}^{-1}\right)$ on newly released soybean varieties and crop geometry $(\mathrm{cm})$ planting in ridge and furrow system

\begin{tabular}{|c|c|c|c|c|c|}
\hline \multirow{2}{*}{ Treatment } & \multicolumn{5}{|c|}{ Crop geometry $(\mathbf{c m})$} \\
\cline { 2 - 6 } & $\mathbf{4 5 \times 5}$ & $\mathbf{4 5 \times 1 0}$ & $\mathbf{4 5 \times 2 0}$ & $\mathbf{4 5} \times \mathbf{3 0}$ & Mean \\
\hline Varieties & \multicolumn{5}{|c|}{} \\
\hline CG Soya 1 & 1786 & 1777 & 1232 & 672 & 1366 \\
\hline RSC 1046 & 1771 & 2101 & 1100 & 927 & 1474 \\
\hline Mean & 1778 & 1939 & 1166. & 799 & \\
\hline & S.Em \pm CD $(\mathrm{P}=0.05 \%)$ & & & \\
\hline Varieties & 18.90 & 53.53 & & & \\
\hline Crop geometry (cm) & 51.70 & 159.33 & & & \\
\hline Interaction & 14.90 & 58.53 & & & \\
\hline
\end{tabular}

\section{Economics fesibilities}

To examine the economic feasibility and viability of different treatment under investigation, economics of soybean production in terms of gross return, net return and net return per rupee investment were calculated for different treatments of soybean and the outcome is presented in Table 4.The cost of cultivation same in variety but varies as crop geometry. The data revealed that significantly highest gross return in variety RSC 1046 and lowest in variety CG Soya 1. Crop geometry $(\mathrm{cm})$ was recorded significant highest gross return in $45 \times 10$ and lowest in $45 \times 30$. The significant highest net return in variety RSC 1046 and lowest in variety CG Soya 1. Crop geometry $(\mathrm{cm})$ was recorded significant highest gross return in $45 \times 10$ and lowest in $45 \times 30$. Net return per rupee investment are significant highest in variety RSC 1046 and lowest in variety CG Soya 1 . Crop geometry (cm) was recorded significant highest gross return in $45 \times 10$ and lowest in $45 \times 30$. Similar results have been noted by ${ }^{[23,24]}$. The increase in gross and net return obviously due to higher seed yield. Less input cost and higher economical yield may be resultant in increase the B: $\mathrm{C}$ ratio. Similar results were also reported by ${ }^{[25,26]}$. It reveals that higher net return of Rs 32920 per ha with $\mathrm{B}$ : C ratio of 3.35 is recorded in ridge and furrow system whereas, the lowest net return of 24660 per ha with and $\mathrm{B}$ : C ratio of 2.82 was recorded under normal flatbed sowing for year $2011^{[6]}$.

\section{Economics of cultivation assessment}

\begin{tabular}{|c|c|c|c|c|}
\hline Treatments & Cost of cultivation $\left(\mathrm{Rs} \mathrm{ha}^{-1}\right)$ & Gross return $\left(\right.$ Rs ha $\left.^{-1}\right)$ & Net return $\left(\right.$ Rs ha $\left.^{-1}\right)$ & Net return rupee ${ }^{-1}$ investment $\left(\right.$ Rs ha $\left.^{-1}\right)$ \\
\hline \multicolumn{5}{|c|}{ Varieties } \\
\hline CG Soya 1 & 23966 & 46366 & 22400 & 0.93 \\
\hline RSC 1046 & 23966 & 50030 & 26064 & 1.08 \\
\hline SEm \pm & & 505.60 & 505.38 & 0.021 \\
\hline $\mathrm{CD}(\mathrm{P}=0.05 \%)$ & & 1985.24 & 1984.37 & 0.08 \\
\hline \multicolumn{5}{|c|}{ Crop geometry $(\mathrm{cm})$} \\
\hline $45 \times 5$ & 25053 & 60322 & 35269 & 1.40 \\
\hline $45 \times 10$ & 24001 & 65780 & 41779 & 1.74 \\
\hline $45 \times 20$ & 23475 & 39558 & 16083 & 0.68 \\
\hline $45 \times 30$ & 23337 & 27132 & 3795 & 0.16 \\
\hline SEm \pm & & 1752.28 & 1752.92 & 0.07 \\
\hline $\mathrm{CD}(\mathrm{P}=0.05 \%)$ & & 5399.32 & 5401.31 & 0.22 \\
\hline
\end{tabular}




\section{Conclusion}

There research programme was recorded variety RSC 1046 best performance as compared to CG Soya 1 in terms of growth parameters, yield attributes and yield. Crop geometry was performance recorded in $45 \times 10$ higher in terms of growth parameter, yield attributes and yield as compared to all other crop geometry. Interaction effect in seed yield. Variety RSC 1046 and crop geometry $(\mathrm{cm}) 45 \times 10$ was recorded significant higher seed yield as compared to all combination planted on ridge and furrow system. Relationship between plant population and seed yield $\left.(\mathrm{kg} \mathrm{ha})^{-1}\right)$ was linear with performance maximum in variety RSC 1046 and crop geometry (cm) $45 \times 10$. Result shows best economics fesibilies was recorded in variety RSC 1046 and lowest in CG Soya 1. Crop geometry was recorded in economics fesibility highest in $45 \times 10$ and lowest in $45 \times 30$. All over things economics are greater perform to variety RSC 1046 and crop geometry $45 \times 10$.

\section{References}

1. Iita. Soybean Production Training Manual. International Institute of Tropical Agriculture, USA, 1992, 341p.

2. Iita. Archival report (1988-1992), crop improvement division, grain legume improvement program part III. International Institute of Tropical Agriculture, Soybean Biological Nitrogen Fixation, 1993, 10p.

3. Acikgoz E, Sincik M, Karasu A, Tongel O, Wietgrefe G, Bilgili $\mathrm{U}$ et al. Forage soybean production for seed in mediterranean environments. Field Crops Research. 2009; 110:213-218.

4. Sattar MA. Biofertilizer in Bangladesh: Problem and prospect. In: Proc. third national workshop on pulses, 1112 June, 2001. BARC, Farmgate, Dhaka. 2001; 1207:95102.

5. Anonymous, 2018. www.indiastat.com

6. Basediya AL, Mishra S, Gupta R, Kumar P, Basediya SS. Performance of Ridge and Furrow System on the Growth and Yield Attribution of Soybean in Barwani District of M.P. India. International Journal Current Microbiology Applied Sciences. 2018; 7(8):499-505.

7. Tiwari SP. Raising the yield ceiling in soybean. An Indian overview. Soybean Research. 2014; 12(2):1-43.

8. Gupta R, Kulmi GS, Basediya AL, Jadav M. Influence of furrow irrigated raosed bed seed drill on growth characteristics and yield of soybean in Mandsaur district of Madhya Pradesh, India. Plant Archives. 2018; 18(1):320-324.

9. Raut VM, Taware SP. Comparison of different sowing methods in soybean. Journals Maharashtra Agriculture. University. 1997; 25(2):218-219.

10. Dhakad SS, Vijay Agrawal, Sanjeev Verma. Effect of ridge and furrow system on the growth character and productivity of rainfed soybean in Vidisha district of M.P. Research Environment. Life Sciences. 2014; 7(3):211-212.5.

11. Donald. In search of yield. Journal of Australian Agricultural Science. 1962; 28:171-178.

12. Pendersen P, Lauer JG. Corn and soybean response to rotation sequence, row spacing and tillage system. Agronomy Journal. 2003; 95:965-997.

13. Rahman MM, Rahman MM, Hossain MM. Effect of row spacing and cultivar on the growth and seed yield of soybean (Glycine max [L.] Merrill) in Kharif-II season. The Agriculturists. 2013; 11(1):33-38.
14. Reddy VR, Timlin DJ, Pachepsky YA. Quantitative description of plant density effects on branching and light interception in soybean. Biotronics. 1999; 28:73-85.

15. Rahman MM, Hossain MM. Plant density effect on growth, yield and yield components of two soybean varieties under equidistant planting arrangement. Asian Journal of Plant Sciences. 2011; 10(5):278-286.

16. Blumenthal MJ, Quach VP, Searle PGE. Effect of soybean population density on soybean yield, nitrogen accumulation and residual nitrogen. Australian Journal of Exp. Agrriculture. 1999; 28:99-106.

17. Shamsi K, Kobraee S. Soybean Agronomic response to plant density. Annals of Biological Research. 2011; 2(4):168-173.

18. Ralli S, Dhingra KK. Response of soybean to different planting methods. Annals of Biology. 2003; 19(2):151155.

19. Ibrahim ME. Response of determinate and indeterminate soybean cultivars to planting pattern and density. Annual Agriculture Science. 1996; 34:1431-1456.

20. Boydak E, Simsek M, Gercek S. Row spacing and irrigation interval effects on yield and yield components of soybean [Glycine max (L.) Merrll]. Pakistan Journal of Biological Sciences. 2004; 7(2):230-234.

21. Malek MA, Shafiquzzaman M, Rahman MS, Razi M. Standardization of soybean row spacing based on morpho-physiological characters. Legume Research. 2012; 35(2):138-143.

22. Singh G. Response of soybean [Glycine Max (L) Merrill] genotype to plant population and planting geometry in Northern India. International Journal of Agricultural Research. 2011; 6(8):653-659.

23. Singh VP, Misra JS, Bhan VM. Effect of varieties, row spacing and weed control measures on weed growth and grain yield of soybean. Pestology. 2000; 24(11):22-24.

24. Pandya N, Chouhan GS, Nepalia V. Effect of varieties, crop geometries and weed management practices on growth and development of soybean, (Glycine max [L.] Merrill) and associated weeds. Indian Journal of Agronomy. 2005; 50(3):218-220.

25. Vyas MD, Khandwe R. Effect of row spacing and seed rate on morpho-pysiological parameters, yield attributes and productivity of soybean [Glycine max (L.) Merrill] cultivars under rainfed condition of Vindhyan Plateau of Madhya Pradesh. Soybean Research, 2014, 82-91.

26. Shivakumar BG, Ahlawat IPS. Integrated nutrient management in soybean (Glycine max)-wheat (Triticum aestivum) cropping system. Indian Journal of Agronomy. 2008; 53(4):273-278. 